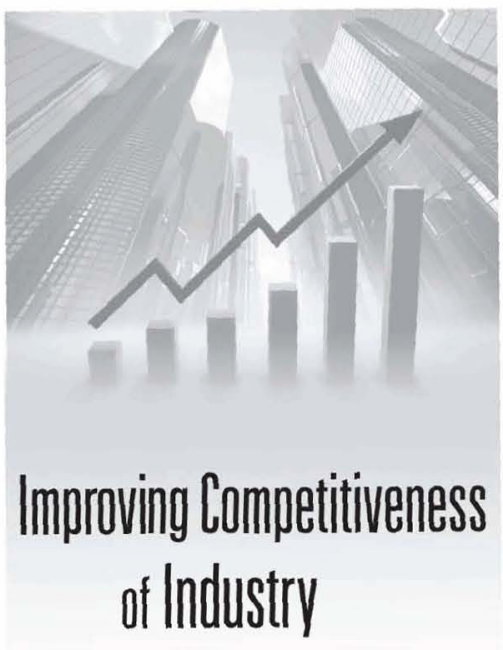




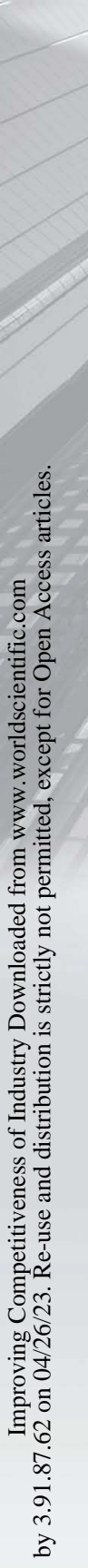

\section{Improving Competitiveness \\ of Industry}

Harold Bierman, Jr

Cornell University, USA 


\section{Published by}

World Scientific Publishing Co. Pte. Ltd.

5 Toh Tuck Link, Singapore 596224

USA office: 27 Warren Street, Suite 401-402, Hackensack, NJ 07601

UK office: 57 Shelton Street, Covent Garden, London WC2H 9HE

\section{British Library Cataloguing-in-Publication Data}

A catalogue record for this book is available from the British Library.

\section{IMPROVING COMPETITIVENESS OF INDUSTRY}

Copyright (C) 2011 by World Scientific Publishing Co. Pte. Ltd.

All rights reserved. This book, or parts thereof, may not be reproduced in any form or by any means, electronic or mechanical, including photocopying, recording or any information storage and retrieval system now known or to be invented, without written permission from the Publisher.

For photocopying of material in this volume, please pay a copying fee through the Copyright Clearance Center, Inc., 222 Rosewood Drive, Danvers, MA 01923, USA. In this case permission to photocopy is not required from the publisher.

ISBN-13 978-981-4335-97-3

ISBN-10 981-4335-97-5

Typeset by Stallion Press

Email: enquiries@stallionpress.com

Printed in Singapore. 
This page is intentionally left blank 


\section{Preface}

As the twenty-first century begins, the world finds itself with a wide range of possible economic futures. Many corporations conclude that it is difficult to compete in international markets with the result being shrinking revenue. Too many governments utilize an excessively high percentage of their nation's goods and services. Bankrupt Greece is buying costly submarines and fighter planes.

In the past, some countries could afford to have a less than perfect tax system. However, wage and other labor rigidities (work rules) handcuff management. Management has become preoccupied with non-productive pursuits, and numerous other sources of inefficiency.

The objective of this book is to suggest several revisions in institutional structure, management techniques and rewards, and a drastic change in how hourly labor is paid. The suggestions offered are applicable to any economy where decisions have to be made as to how to organize the factors of production most efficiently.

I readily concede that the exact initiation of implementation of many of my suggestions will be difficult. However, it is essential that a start be made toward an industrial economic system that is efficient as well as fair.

Harold Bierman, Jv.

Cornell University

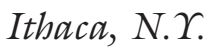


This page is intentionally left blank 


\section{Acknowledgments}

My primary facilitator on this project was my support aide and typist, Barbara Drake. She was efficient and reliable and always cheerful.

My son, H. Scott Bierman, helped with a segment of the book. Sy Smidt helped me develop key ideas regarding capital budgeting.

For better or worse, the book is primarily the result of my efforts. I cannot assign blame to others.

Harold Bierman, Jr. 
This page is intentionally left blank 


\section{Contents}

Preface $\quad$ v

Acknowledgments vii

Chapter 1 An Agenda for Increasing Productivity: 1 An Introduction

Chapter 2 Corporate Tax Modification Proposals 5

Chapter 3 Productivity and the Net Present Value 13 Calculation

Chapter 4 A Managerial Incentive Strategy for Increased 21 Productivity

Chapter 5 Economic Income 35

Chapter 6 Flexible Wages: A Wage Plan for Increased 47 Productivity

$\begin{array}{lll}\text { Chapter } 7 & \text { Industrial Democracy } & 59\end{array}$

Chapter 8 Correcting One Problem: Introducing Present 71 Value Depreciation

Chapter 9 Using Earnings Per Share and Stock Prices to Measure Managerial Performance 
Chapter 10 Ten Management Errors

Chapter 11 Costs of Capital by Division

Chapter 12 Mergers, Acquisitions, and LBOs

Chapter 13 Little Differences and Big Results 109

Chapter 14 Scientific Management

Chapter 15 Corporate Strategies

Chapter 16 Achieving an Improved Competitive Position 